\title{
TRANSNACIONALIZACIÓN DE LAS DANZAS AZTECAS Y RELOCALIZACIÓN DE LAS FRONTERAS MÉXICO / ESTADOS UNIDOS
}

\author{
Renée de la Torre (Ciesas Occidente) \\ Cristina Gutiérrez Zúniga (El Colegio de Jalisco)
}

El presente artículo trata sobre el papel que juega la rehabilitación, reinvención y rescate de mitos fundacionales, símbolos nacionales y rituales transfronterizos basados en la búsqueda de raíces etno-nacionales en un contexto transfronterizo. ${ }^{1}$ En particular compararemos una misma celebración (de reciente invención) en torno al último emperador Azteca que se lleva a cabo simultáneamente en Tijuana (Baja California, México) y en Los Ángeles (California, Estados Unidos). Estas poblaciones forman parte de una región fronteriza, que aunque se encuentran dividida por una muralla, es a la vez un lugar de encuentro con la multiculturalidad y con la alteridad nacional. Es como lo señala Homi Bhabha un lugar "in-Between" (en el entre) de dos regímenes nacionales, que a su vez reconfiguran la identidad étnica y la ciudadanía.

Veremos el ritual como el lugar donde escenifica una narrativa basada en el rescate de las raíces aztecas de la mexicanidad, para atender la manera en que esta narrativa contribuye a reivindicar una nación imaginada allende las fronteras, ${ }^{2}$ que se legitima recurriendo a la memoria fundacional del imperio azteca. Esta nación imaginada se genera a partir de actores urbanos situados en los márgenes del Estado que crean "contranarrativas de origen de naciones primeras y formas de nacionalismo invertidas y esencializadas".

\footnotetext{
${ }^{1}$ Este trabajo forma parte del proyecto: "Transnacionalización y relocalización de las religiones indo y afro americanas" (CONACYT 81926), coordinado por Renée de la Torre. Una primera versión fue presentada en el Coloquio del proyecto en París, febrero del 2009.

${ }^{2}$ Una nación construida sobre la idea de una comunidad abarcadora que permite que los individuos se sientan parte de ella sin conocerse entre sí y a pesar de la imposibilidad de interacción cara a cara (Anderson, 1991).
} 
Incluso su concepción de nación, al ser una narrativa que transversaliza lo binacional, es capaz de generar un "transnacionalismo desde abajo." (Smith; Guarnido, 1998; apud Capone; Mary, s/f).

Es en el tema de la generación de transnacionalismos desde abajo, o desde los márgenes, que se sitúa el presente trabajo, pues atendemos prácticas y narrativas que se producen en las periferias y que migran en sentido inverso al imperialismo, y que en lugar de generar poderes unidireccionales, generan flujos "multidireccionales" de bienes, prácticas e instituciones religiosas (Csordas, 2009, p. 4).

Diversas ceremonias rituales, como son las vinculadas a la danza azteca y en particular el homenaje a Cuauhtémoc, contribuyen a crear una semblanza de verdad (autenticidad) en la cual se sustenta la ancestralidad del linaje étnico-racial azteca de una nación "original” concebida como Aztlán. Esta nación imaginada, debido a que desempolva y reivindica la memoria de un territorio que abracaba los dos estados nacionales divididos hoy por una frontera, constituye una nación transnacionalizada.

Por último, atenderemos el ritual como un acto performativo (y no solo comunicativo) en la medida en que es capaz de generar una comunidad étinca-nacional imaginada adscrita a nuevos espacios sagrados. En este sentido proponemos que la ceremonia a Cuauhtémoc como principal ceremonial del movimiento de la mexicanidad, contribuye a redefinir simbólicamente el territorio fronterizo bajo dominios de imaginarios de identidad ancestral que proyectan la utopía postcolonial del regreso a los orígenes como a una tierra prometida donde se cumplirá el despertar de una civilización negada por el mundo occidental, el capitalismo, y el modernismo. El lugar de fronteras genera continuamente desterritorialización y reterritrorializaciones, por lo cual permite, como ya lo señaló Néstor García Canclini (1989), atender las entradas y salidas de la modernidad.

Un importante antecedente sobre la capacidad de las danzas aztecas en la construcción de la tradición chicana en California (Estados Unidos) fue el trabajo de Mariágela Rodríguez (2005), quien destacó el papel performativo de la danza para, por un lado, dramatizar la experiencia histórica de desterritorialización y reterritorialización de los chicanos (mexicanos residentes de 
Estados Unidos) en la ciudad de Los Ángeles, y en un segundo momento reconstruir su historia e identidad. En nuestro caso particular, la selección de un ritual simultáneo en ambos lados de la frontera se debe a que, como lo desarrollamos en un trabajo anterior, consideramos que éste acto posee la eficacia simbólica para rescatar y conquistar la memoria histórica de un pasado idealizado como glorioso, que permite imaginar una nación alternativa a la demarcada por los estados modernos, ${ }^{3}$ pero generada - como lo plantea Chatejee (1996) - desde los márgenes.

Por un lado, el ritual será retomado como un acto performativo ${ }^{4}$ que resimboliza y narra una nación imaginada, basada en un mito ancestral y que conduce una utopía para construir otros accesos para ingresar a la modernidad. Consideramos el ritual, como una acto narrativo (simbolizado y ritualizado) de la nación, que como sugiere Bhabha "emerge como un efecto de semejante «significación incompleta» es una transformación de las fronteras $y$ límites en espacios in-between a través de los cuales los significados de autoridad cultural y política son negociados (Bhabha, 2000, p. 218).

Compartimos la hipótesis de que la migración y la movilidad generadas por los flujos de bienes materiales, humanos y simbólicos lejos de debilitar los rasgos de autenticidad e identidad nacional y étnica, contribuyen a revalorar, reinventar y recuperar etnicidades, debido a que, por un lado lo "étnico puro" se ha convertido en uno de los instrumentos más flexibles de la invención cultural, y lo global está definitivamente incorporado en las

\footnotetext{
${ }^{3}$ El concepto de nación imaginada lo retomamos de Benedict Anderson, quien la define como una construcción narrativa sobre la idea de una comunidad abarcadora que permite que los individuos se sientan parte de ella sin conocerse entre sí y a pesar de la imposibilidad de interacción cara a cara (Anderson, 1991), Sin embargo a diferencia de este autor, consideramos que las naciones imaginadas pueden ser también construidas desde los márgenes, y no solo por los estados (Chaterjee, 1996).

${ }^{4}$ Retomamos la concepción performativa del ritual propuesta por Victor Turner quien inspirado en la teoría de los actos performativos del habla de Austin que le confería a éstos no solo un función comunicativa sino una forma de acción. En este sentido Turner ve el ritual como un acto realizativo, en donde el drama social no solo expresa la experiencia vivida, sino que además es capaz de recrear una sociedad ideal o de realizar el conflicto (Véase Turner, 1980).
} 
formas aparentemente más arcaicas de la "comunidad indígena" (Galinier; Molinié, 2006, p. 9). Y por otro lado, a que la necesidad de arraigo local, étnico y nacional adquiere carácter prioritario, contribuyendo a que, como sugiere Stefania Capone, las raíces, en lugar de desvanecerse, se multipliquen y se desplacen a otros territorios (Capone, 2004).

En particular se eligió la celebración del aniversario del Tlatoani Cuauhtémoc, ${ }^{5}$ el más importante héroe del panteón azteca, en el cual confluyen distintos actores: chicanos, seguidores del movimiento de la mexicanidad, danzantes tradicionales concheros, y buscadores new age de espiritualidades indígenas. Lo interesante de dicha ceremonia es que siendo un ritual cívico-espiritual de reciente invención, está referido a generar la idea de continuidad de un linaje étnico prehispánico: la raza azteca. El estudio se basa en una monografía de la celebración que se realiza simultáneamente en ambos lados de la frontera México/Estados Unidos: el Homenaje a Cuauhtémoc en Tijuana (lado mexicano) y en Los Ángeles (del lado estadounidense).

\section{LA MEXICANIDAD Y LA DANZA: RITUALIDAD QUE ACTUALIZA UNA NARRATIVA DEL REGRESO A LOS ORÍGENES}

La danza azteca o mexica es actualmente una práctica ritual de reciente invención, pero que contribuye a un programa de rescate de las raíces ancestrales. Existen múltiples versiones antagónicas al interior de este movimiento que contribuyen a redefinir estílisticamente e ideológicamente al movimiento. Esta disputa polémica se sitúa en un debate entre la mexicanidad radical el rescate de lo puro (danzas mexicas esencializadas), lo sincrético-tradicional (danzas concheras-aztecas que forman parte del sistema de religiosidad popular), y la neo mexicanidad (basada en un nuevo eclecticismo que reinterpreta lo prehispánico bajo el crisol de una matriz new age).

Creemos que la mejor manera de caracteriza la expresión estílística e identiraria de la danza en el contexto fronterizo es como hibridación

\footnotetext{
5 Tlatoani es la autoridad en náhuatl, Cuauhtémoc fue el último emperador del imperio Azteca y es considerado como el primer héroe nacional de México.
} 
cultural (García Canclini, 1990). Este concepto permite atender el cruce entre las culturas tradicionales y la modernidad contemporánea. Por ello la antropología se plantea no solo mirar hacia las resitencias culturales, sino también a las transformaciones profundas que lo popular y la tradición están sufriendo en relación con los efectos de la urbanización, la globalización cultural provenientes de los flujos de información mediática, de los flujos migratorios, de los flujos mercantiles y de los flujos de la tecnologías cibernéticas. Esta interacción a su vez provoca nuevas culturas en las que las distinciones de clase, y las distinciones entre alta cultura y cultura popular, van perdiendo sentido. Podemos corroborar la tendencia de la mexicanidad hacia la generación de nuevos hibridismos culturales y eclecticismos religiosos que, incluso recrean el "neobarroco" basado en sobreponer imágenes del mestizo o el indio mexicano a partir de una sobreabundancia y ficcionalización de la identidad; no obstante, como lo advierte Serge Gruzinski, habrá que tener cautela con: "[...] los márgenes que se liberan pero también las trampas que encierra esta aparente libertad, este aparente desorden de lo imaginario" (Gruzinski, 1990, p. 214). Por ello buscaremos no perder de vista que, aunque consideramos la danza bajo una óptica de los proceso de hibridación, contínua siendo una práctica donde se continúa disputando la tensión imbricada en la construcción del mestizaje nacional.

Dentro de este sistema simbólico, la danza ritual tiene una relevancia en la confrontación cultural. Por un lado los conquistadores españoles recurrieron a la asimilación de las danzas prehispánicas para escenificar la conquista (denominándolas como danzas de conquista), y permitieron esta práctica en relación a la estrategia de sustitución de las divinidades indígenas por imágenes cristianas (Warman, 1972). Por otro lado, algunos pueblos indígenas han practicado la resistencia cultural activando un simulacro que oculta bajo las formas católicas a los cultos indígenas (De la Torre, 2008). Más recientemente, a mediados del siglo XX la danza (transformada en conchero-azteca) fue revalorada por los sectores urbanos populares como la fuente más legitima para recuperar el sentido indígena de lo "azteca". Posteriormente, la danza ha sido fuente de inspiración de procesos de resignificación que tienden a una esencialización de la danza prehispánica 
o "mexhica", basados en la recuperación de la "pureza del pasado indígena", reculturalizando la danza hacia una tendencia indianista, nacionalista y azteca que rechaza el sincretismo con el catolicismo, con la cultura hispánica y con la cultura moderna occidental (De la Peña, 2002, p. 96).

\section{PROPUESTA METODOLÓGICA}

Nuestra atención entonces se centrará en la eficacia simbólica del ritual, como constructor de circuitos de circulación que permiten articular narrativas que redibujan espacios y tiempos de representación y acción para generar un lugar entre-fronteras y una identidad transfronteriza binacional.

Los rituales en torno a Cuauhtémoc han sido instaurados por los miembros del movimiento denominado como mexicanidad, que se basa en el rescate idealizado de la cultura de los pueblos prehispánicos, pero con mayor énfasis en la restauración de lo azteca. ${ }^{6}$ Entre los chicanos, este movimiento ha sido reapropiado para generar su propia identidad y el reconocimiento de su ciudadanía cultural como mexicanos pobladores de Estados Unidos, para ello:

Ha generado creencias, mitos y prácticas en torno a la rehabilitación de Aztlán, una nación imaginada sustentada en la sacralización ritual de "santuarios de la mexicanidad" que funcionan como lugares nodales o de convergencia de un territorio imaginado sobre la base de un imperio antiguo y que pretenden articular un espacio cultural que hoy se encuentra fragmentado por una frontera física-política que divide a Estados Unidos y México. El movimiento en torno a la reivindicación de "la nación espiritual de Aztlán"7 tiene como meta crear puentes simbólicos que vinculen a la

\footnotetext{
${ }^{6}$ En nacionalismo oficial, construyó una narrativa centralizada en lo "azteca” a través de las ceremonias cívicas, los museos y los símbolos nacionales, en detrimento de la diversidad étnica presente en la historia de este país.

${ }^{7}$ Cuando hablamos de nación imaginada lo hacemos a partir de la narrativa propia del movimiento chicano que se autoconcibe como nación espiritual, es decir heredera de una cultura y una utopía, pero no como un estado nación, formación que como muestra Anderson nace con la Ilustración.
}

Debates do NER, Porto Alegre, ANo I3, N. 2I P. II-48, JAN./Jun. 2012 
población mexicana que habita a ambos lados de dicha frontera (De la Torre; Gutiérrez Zúñiga s/f).

Se busca resaltar la ceremonia como un acto simbólico-ritual para crear un puente entre un territorio y una población dividida por dos regímenes nacionales. La elección de este objeto de estudio multi-situado, tiene como objetivo comparar los actores, símbolos y sentidos que conforman cada uno de los rituales a fin de entender el sentido cultural que generan en cada contexto nacional estudiado. Partimos de la idea de que la globalización no sólo no desdibuja las identidades étnicas y nacionales, sino que contribuye a su reformulación. Por ello, con este ejercido antropológico, buscamos responder a: ¿Las movilidades propias de la globalización debilitan los marcos de identidad o conducen a la reformulación y fortalecimiento de etnizaciones primarias y naciones imaginadas? ¿Qué papel juegan las narrativas de naciones primigenias en la construcción de transnacionalismos desde abajo? ¿Qué papel juegan los rituales en la generación de novedosas identidades, memorias y enraizamientos territoriales? ¿En qué medida contribuye la recuperación de rituales que miran al pasado en la producción de utopías postnacionales? ¿Cuál es su eficacia hacia simbólica?

Nuestra metodología se basa en los aportes de la antropología contemporánea que contempla el trabajo de campo multi-situado (Marcus, 1995), a fin de observar e incorporar en la etnografías los trayectos y circuitos de los líderes y los practicantes religiosos, pero sin desatender "[...] las historicidades construidas y disputadas, los sitios de desplazamiento, interferencia e interacción" (Clifford, 1999, p. 38). La presente etnografía se realizó como un esfuerzo colaborativo entre las dos autoras: Renée de la Torre se encargó del registro de la festividad en Tijuana y ristina Gutiérrez Zúñiga de los Ángeles. ${ }^{8}$ Sin embargo, la redacción se realizó de manera conjunta

\footnotetext{
${ }^{8}$ Este trabajo contó con la valiosa participación de dos jóvenes danzantes e investigadoras: Olga Olivas y Priscila Viera (ambas maestras en estudios culturales de El COLEF y la UABC), sin las cuales no hubiéramos tenido la posibilidad de cubrir los trayectos y la densidad requerida para el ejercicio etnográfico multisituado. Ellas nos introdujeron en los grupos y las redes fronterizas, y nos apoyaron con la realización posterior de entrevistas y registros de otras festividades.
}

Debates do NER, Porto Alegre, ANo I3, N. 2I P. II-48, JAN./JUn. 2012 
a fin de mantener los mismos ejes de contraste y similitud. El trabajo de campo consistió en registros audiovisuales y de diario de campo de las dos festividades; historias de vida con los líderes y entrevistas con participantes, reconstrucción de los grupos de danzas, análisis comparativo de los líderes, considerados para propósitos analíticos como actores nodos; ${ }^{9}$ y reconstrucción de sus trayectos e itinerarios, ${ }^{10}$ poniendo atención a sus recorridos transnacionales y transculturales, pues es ahí donde se tejen encuentros con la diversidad. Se puso central atención en los trayectos tanto de los líderes como de los "buscadores espirituales" ya que es mediante éstos que los actores van entretejiendo circuitos ${ }^{11}$ y construyendo puentes entre distintas redes, ${ }^{12}$ configurando así novedosas interfases entre movimientos o conjuntos disímbolos.

\footnotetext{
${ }^{9}$ Entendemos por actor nodo: al actor o ego central que condensa relaciones, debido a sus múltiples trayectos biográficos va tejiendo relaciones y articulaciones entre distintos circuitos. Los actores nodos pueden ejercer liderazgo múltiple en distintos circuitos que participan de la red. Retomamos la siguiente definición para la operacionalización de su análisis: "El punto de articulación entre el conjunto de un ego (ya sea un individuo o una familia) y la red (o campo social) que se expande por todos lados, reside en el hecho de que los vínculos "laterales" entre unidades del conjunto, distintas del ego, constituyen al mismo tiempo, elementos en otros conjuntos centrados en torno a tales unidades [...]" (Degenne; Forsé, 1994, p. 29).

${ }^{10}$ Los trayectos e itinerarios se refieren a las "rutas individuales" que, a partir, de la totalidad de la oferta, conforman un sintagma particular, permitiendo identificar tipos de usuario, de espacios, de productos y de prácticas existentes (Magnanni, 1999).

${ }^{11}$ Retomamos el concepto de circuito ofrecido por Magnanni, quien propone entender un padrón de la distribución y articulación de establecimientos que permiten el ejercicio de sociabilidad por parte de usuarios habituales. Ello no supone necesariamente una contiguidad espacial, ni una membresía, pero sí una articulación por prácticas típicas (Magnanni, 1999).

${ }^{12}$ Por red entendemos los enlaces entre personas y grupos. Así como las conexiones entre los enlaces mismos.
} 


\section{NODO: 1. LAS CALIFORNIAS: UN TERRITORIO TRANSFRONTERIZO}

La frontera México-Estados-Unidos mide dos mil kilómetros de largo. Esta frontera divide el territorio californiano que fue colonizado por los españoles y formó parte del Virreinato de la Nueva España; se independizó en 1821 y formó parte de México hasta 1848 cuando, al final de la guerra entre México y Estados Unidos, la parte norte o Alta California fue "comprada" al Gobierno de México, mientras éste retuvo la zona sur o "Baja California”. La Alta California se convirtió en el Estado norteamericano de California en 1850.

A partir de esta división fronteriza no sólo se estableció una demarcación territorial entre dos naciones con regímenes políticos diferentes, sino que las poblaciones de California reestructuraron sus identidades a partir de este eje que marcó distinciones entre la población de un lado y de otro: americanos y mexicanos (Kearney, 1999). Hubo familias que quedaron divididas por la frontera y cuyas identidades se reformularon. Lo mismo sucedió con algunas tribus o grupos étnicos. Pero como bien sabemos, las fronteras no solo dividen y demarcan identidades diferenciadas y desniveladas, sino que también construyen zonas de contacto entre ambos territorios y culturas (Hannerz, 1997).

Cabe precisar que la frontera también demarca la distinción de dos "formaciones nacionales de alteridad"13 diferentes y contrastantes. En México ser mexicano implica una identidad nacional construida a partir del imaginario de unidad nacional basado principalmente en el mestizaje cultural (mediante la evangelización, la castellanización y la modernización)

\footnotetext{
${ }^{13}$ Las formaciones de alteridad se refieren a "la producción y el trazado de líneas de fracturas propias de procesos históricos particulares que configuran la matriz de producción de diferencias" (Segato, 2007, p. 28).
} 
y el mestizaje racial. ${ }^{14}$ En los Estados Unidos opera un régimen de racialización con base en color. De esta manera cuando un mexicano cruza a los Estados Unidos automáticamente su nacionalidad es considerada como parte de una etnia desprovista de territorio: se le llama "hispano" y se le imprime una clasificación de exclusión concordante con un régimen racial de color: whites (blancos) y browns (cafés) (Quijano, 2000). Con ello el concepto clasificatorio con que opera la etnicidad cobra un sentido racial que no existe en México de manera oficial, por lo que para los mexicanos la narativización de la categoría racial en Estados Unidos le permite inscribirse en un movimiento ciudadano que reivindica el reconocimiento como minoría étnica ciudadana. Sólo así se puede entender que los chicanos se reivindiquen como "raza", término que en México no tienen lugar en el debate. Por su parte, si en México lo políticamente correcto es ser mestizo, al pasar a los Estados Unidos los mexicanos descubren que "indio" en ese otro territorio significa ser nativo americano, y ello confiere la posibilidad del reconocimiento ciudadano. A partir de estas demarcaciones tenemos que buscar responder a los múltiples significantes y significados que atraviesan a los danzantes que reivindican la mexicanidad en la frontera, pero abordaremos la manera en que, según los regímenes nacionales de reconocimiento ciudadano de las diferencias de cada país, los danzantes negocian contenidos de identificación: indianizado, racializado, nativizado o nacionalizado.

Los Angeles es la ciudad más importante del estado de California en términos económicos y poblacionales. De sus aproximadamente 13 millones de habitantes, $48 \%$ es de origen hispano, lo que la convierte en la segunda ciudad con mayor población de origen mexicano del mundo, sólo después

\footnotetext{
${ }^{14}$ La castellanización fue una estrategia de conquista en América y consistió en la imposición de la lengua castellana como idioma oficial en la Nueva España. Por su parte, el mestizaje fue la solución a la unidad nacional en México y en otros países latinoamericanos; sin embargo con ello no queremos decir que no exista racismo, sino que éste existe respecto de los pueblos aborígenes y en cuanto a los desniveles entre las clases sociales (De la Peña, 2002).
} 
de la ciudad de México. Lejos de constituir un conglomerado poblacional urbano que ocupa un territorio definido, ha sido considerada prototípica de una "constelación ex urbana" (Castells, 1999, p. 433) en tanto se encuentra formada por conglomerados habitacionales, de producción y de administración que ocupan territorios discontinuos (no contiguos) y multicéntricos vinculados funcionalmente por los flujos a través de sus vías de comunicación, abarcando más de mil kilómetros cuadrados.

Por su parte, Tijuana ha sido también desde su origen una zona de contacto entre mexicanos y norteamericanos: desde su fundación a finales del siglo XIX funcionó como casino para los gringos, posteriormente adoptó personalidad de zona roja para jóvenes descarriados de California, y en los años 60 se convirtió en corredor industrial de maquila para emplear a los desplazados del programa bracero. Como zona fronteriza también genera espacios liminales, marcados por las travesías que van desde un lugar hacia otro, y por la indefinición normativa que le imprime el ser zona de umbral. Para muchas personas Tijuana se vive como una ciudad colmada de impunidad, inseguridad y violencia. Es una ciudad que se vive como zona de tensión, en parte por los índices de violencia internos provocados tanto por las bandas de delincuencia organizadas, como por la prepotencia policíaca, pero también traspasada por los excesos de la patrulla fronteriza, o por la propia estafa de los "polleros" y "coyotes" - operadores del transporte ilegal - para con los migrantes. Este imaginario de incertidumbre existencial se ha incrementado aun más con la presencia del narcotráfico y sus cárteles en Tijuana.

Mientras que Los Ángeles como parte de la California de los Estados Unidos representa el estado próspero que alberga el sueño de Disneylandia y el glamour de Hollywood, la Tijuana de la California mexicana es imaginada como el lugar sin limites, a donde los californianos asistían para practicar lo prohibido en su país; como anuncia la canción de Manú Chao: "Welcome to Tijuana. Tequila, sexo y mariguana". Es también un espacio liminal porque debido a ser tierra de nadie, continuamente se transgreden 
las normas e incluso la frontera misma, como entona el mismo Manú Chao "con el coyote no hay aduana". ${ }^{15}$

Tanto Los Angeles como Tijuana son ciudades multiculturales, multiétnicas y bilingues, ${ }^{16}$ abigarradas de contrastes sociales internos. En L.A. los hispanos no son mayoría, conviven con "blancos", asiáticos, y afroamericanos y en proporción mínima, con indígenas nativos norteamericanos. ${ }^{17}$ Tijuana es una ciudad que sufre del crecimiento veloz y por tanto desordenado e intenso en los últimos anos causado por la inmigración que experimenta la ciudad como la imposibilidad de pasar la frontera, o porque bien es vista como tierra de oportunidades laborales en la maquila industrial. A inicios del siglo XX era un pequeño poblado de escasos 100 habitantes, en los años 50 tenía 60 mil habitantes, y para el año 2000 Tijuana rebasó el millón de habitantes. (Torres Ramírez, 2004).

Con todo, Tijuana es una sociedad habitada por la multiculturalidad tanto por la diversidad étnica y regional mexicana, cuyos pobladores provienen de toda la república mexicana; como por la presencia creciente de centroamericanos que se establecen ahí temporalmente porque no logran pasar del otro lado. Es también multicultural debido a que diariamente recibe visitantes norteamericanos cuyos origines culturales pueden ser asiáticos, africanos, nativos indígenas, o europeos. $\mathrm{Al}$ respecto, Néstor

15 "As of March 2006, the estimated unauthorized population in the United States was 11.5 to 12 million, of which 4.5 to 6 million entered legally with inspection and 6 to 7 million entered illegally without inspection. On average, there are 700,000 to 850,000 new unauthorized migrants arriving annually by all modes of entry. An estimated 6.2 million (or 56 percent) of al unauthorized migrants are from Mexico." Fuente: estimaciones del Pew Hispanic Center basadas en March 2005 Current Population Survey; Department Homeland Security reports. Disponible en: http://pewhispanic.org/files/ reports/61.pdf. Consultado en: 1 sept. 2010.

${ }^{16}$ En los Ángeles sólo 42\% habla inglés como su primera lengua y 41.7\% español, "Demographics of Los Angeles". Disponible en: http://en.wikipedia.org/wiki/Los_ Angeles\#Demographics. Consultado en: 1 sept. 2010.

${ }^{17}$ Del resto de la población angelina, 30\% son "blancos", $11 \%$ asiáticos, $10 \%$ son afroamericanos y $1 \%$ nativos norteamericanos, ibid. 
García Canclini describió a Tijuana como uno de los mayores laboratorios de la posmodernidad, porque en ella se experimentan:

Las búsquedas más radicales acerca de lo que significa estar entrando y saliendo de la modernidad son las de quienes asumen las tensiones entre desterritorialización y reterritorialización. Con esto me refiero a dos procesos: la pérdida de la relación natural de la cultura con los territorios geográficos y sociales, y, al mismo tiempo, ciertas relocalizaciones territoriales relativas, parciales, de las viejas y nuevas producciones simbólicas (García Canclini, 1990, p. 288).

Tijuana además de vivir de la fragmentación impuesta por la frontera, es también un espacio transterritorial. Muchos de los habitantes de Tijuana acostumbran cruzar la línea fronteriza cotidianamente. Hay quienes residen en Tijuana y trabajan en San Diego, o cruzan cotidianamente la "línea” para hacer sus compras en el "mall" vecino, o pasan los fines de semana al otro lado para pasear (Torres Ramírez, 2004) ${ }^{18}$ En los últimas décadas la línea fronteriza se ha venido endureciendo y materializando en un muro que divide a Tijuana de San Isidro. ${ }^{19} \mathrm{El}$ muro se ha convertido en elemento de reivindicación de un vital movimiento artístico. Pero más allá de la facticidad con que el muro es capaz de dividir y fragmentar, también existen múltiples impulsos creativos (sobre todo desarrollados por movimientos artísticos) que constantemente quiebran la frontera. Uno de ellos es el festejo simultáneo del homenaje a Cuauhtémoc (el último rey azteca) que se celebra en Los

\footnotetext{
18 "In 2004, there was an average of 660,000 passenger crossings per day across 35 points of entry. The United States issued 906,622 nonimmigrant visas for Mexicans in fiscal year (FY) 2005. In addition, 732,566 laser visas (which replaced the old border crossing cards for those who live on the Mexican side of the border but work in the United States) were issued in FY 2005”. Fuente: US Department of State Visa Statistics, disponible en la página "Migration Information Source" generada por el Migration Policy Institute http:// www.migrationinformation.org/Feature/display.cfm?id=407. Consultado en: 1 sept. 2010.

19 "In the Fiscal Year 2004, there were 1,139,282 apprehensions of immigrants on the southern border.. In FY 2005, there were a record-breaking 473 migrant deaths at the border”. (Fuente: US Customs and Border Protection Public Affairs Office), ibid.
} 
Ángeles y en Tijuana el 22-23 de febrero, fechas en las que se calcula sucedió su nacimiento y su muerte a manos de los conquistadores españoles.

Aunque erróneamente se ha pensado que debido a su cercanía e interacción constante con los Estados Unidos, la población fronteriza iría perdiendo sus raíces culturales que la identifican con México, en Tijuana se han ido generando novedosas expresiones que recolocan lo mexicano en una cultura propia: fronteriza (Valenzuela, 2000). Como veremos, los chicanos y los tijuanenses buscan recolocar sus raíces en la apropiación de antiguos mitos como es el de Aztlán, nombre que en la tradición nahua hace referencia al lugar mítico del norte de donde provinieron las tribus pobladoras del Valle de México y que a partir de 1969 se incorporó como territorio sobre el que descansa la construcción simbólica de una nacionalidad transnacional: la chicana (Rodríguez, 2005). También se ha instaurado una ritualidad transfronteriza, que hermana a chicanos con mexicanos, que rearticula las identidades de los grupos nativos de un lado y otro de la frontera, que los posiciona en condiciones de reivindicar sus derechos ciudadanos como grupo étnico y racial (con el movimiento afro americano) en los Estados Unidos. Estas actividades de producción simbólica que permean el arte, el folklore y las tradiciones son impulsos con los que los habitantes de un lado y de otro atraviesan y perforan constantemente el cerco fronterizo. En este trabajo nos enfocaremos al análisis etnográfico de un ritual transfronterizo: la danza azteca en la fiesta a Cuauhtémoc.

\section{ANTECEDENTES DE LAS DANZAS TRASFRONTERIZAS Y LA FIESTA A CUAUHTÉMOC}

La Fiesta de Cuauhtémoc en Los Ángeles se remonta a 1980, cuando las autoridades de Los Ángeles le piden a un conocido danzante y coreógrafo, Florencio Yescas, que se presente con su grupo Esplendor Azteca para participar en la ceremonia de inauguración del monumento a Cuauhtémoc en el Parque México. Esta fiesta se encuentra entonces vinculada desde su inicio a los orígenes de la danza azteca en los Estados Unidos, ya que la mayor parte de los grupos reconocidos como "de tradición" en el 
Sur de California fueron fundados por Florencio Yescas o sus discípulos. Asimismo, esta celebración fue reconocida por los grupos de la Ciudad de México como parte de los homenajes que los grupos concheros le rinden al último emperador azteca y autor de la consigna de Cuauhtémoc, según la cual el último emperador azteca antes de su capitulación en 1521 pedía que se ocultara el rico conocimiento indígena y se conservara por medio de la tradición oral.

Algunos de los rasgos de la trayectoria de este maestro proveen las claves con la que la danza es practicada en los Estados Unidos: como espectáculo, como tradición y como política.

Florencio Yescas provenía del grupo del General Pineda en la Ciudad de México. Sin embargo también era parte del Ballet Folklórico Nacional (Amalia Hernández), una compañía que realizaba una versión estereotipada, engrandecedora y teatral de la danza azteca, alimentada por una política cultural oficial que buscaba la proyección del indio como raíz genuina del nacionalismo mexicano. Fue invitado en 1973 a los Estados Unidos por el Centro Cultural La Raza, de San Diego, un centro formado desde los años sesentas por intelectuales y artistas chicanos en búsqueda de la reivindicación cultural y política de la población hispana y migrante en un contexto de fuerte racismo. Funda el primer grupo de danza azteca tomando el nombre del núcleo de intelectuales, Toltecas en Aztlán que lo habían invitado. El maestro da clases de folklórico a jóvenes de origen mexicano nacidos en los Estados Unidos que se encontraban "en busca de raíces" mexicanas indígenas, más allá de la versión hispanizada de lo mexicano representada por la charrería y estudiantina. Pero a la vez representa danzas aztecas en distintas ceremonias y actos públicas, integrándose a la demanda de reconocimiento y reivindicación de los chicanos y migrantes. Dos años más tarde, comienza a participar en las actividades político culturales de Chicano Park, antiguo estacionamiento de la Border Patrol arrebatado mediante luchas civiles y convertido en sitio emblemático de la lucha por los derechos de los chicanos en los Estados Unidos. Poco después, Yescas marcha a Los Angeles y funda un nuevo grupo, Esplendor Azteca. Con ellos realiza un gran proyecto de escenografía, vestuarios y coreografías teatrales para Disneylandia. Al mismo 
tiempo, impulsa el reconocimiento de Toltecas de Aztlán por parte de generales de la danza en México, como Francisco Díaz y Manuel Pineda, y con ese fin viaja con varios de sus discípulos chicanos a la Ciudad de México. A su vez, participa en el Congreso del Quinto Sol, promovido por grupos del Movimiento de la Mexicanidad, movimiento de reivindicación que busca rescatar la cultura indígena de México purificándola de todo sincretismo con el catolicismo o la cultura de los conquistadores. El grupo de San Diego, Toltecas de Aztlán, desde la marcha de Yescas a Los Ángeles intenta un liderazgo colectivo que no funciona. Sus miembros participan en distintos movimientos culturales y políticos - comunidades utópicas de tipo hippie, movimiento nativo americano (White Roots of Peace y la Native American Church) grupos de neomexicanidad (Tlacaélel), la reivindicación chicana por los derechos ciudadanos (como el Movimiento Estudiantil Chicanos de Aztlán, MECHA) - experiencias y vínculos que los diferencian entre sí, construyendo sus propias redes. Entre 1981 y 1985, cuando muere Florencio Yescas, los discípulos fundan seis grupos de danza distintos en Los Angeles, San Diego, Pasadena, Phoenix y Nuevo México, a partir de los cuales a su vez se han fundado un sinnúmero de grupos en los EUA. En la actualidad los discípulos de Yescas se encuentran activos articulando diversas redes (actores nodos) políticas y culturales. Varios de ellos se encuentran en proceso de sucesión de los capitanes de la siguiente generación. ${ }^{20}$

Hemos detectado diversos ejes de conflicto en esta tupida red de danzantes, todos ellos derivados de la práctica ecléctica de Yescas en el contexto estadounidense: a) el posicionamiento político en relación al movimiento chicano y de defensa de los migrantes y el papel de la danza respecto a él; b) la práctica de la danza como espectáculo; c) la relación con las autoridades gubernamentales para lograr el financiamiento de la danza y sus actividades

${ }^{20}$ Esta reconstrucción de la historia de la danza azteca en el sur de California se realizó a partir de las entrevistas a los capitanes de danza Virginia Carmelo (Xipe Totec de los Angeles) Mary Lou Valencia (Mixcoatl de San Diego) y Maggie Calderón (Fuego Nuevo de Altadena), Mario Aguilar (Mexicáyotl de San Diego), así como Rosita Maya. Asimismo fue una fundamental referencia la tesis de maestría en Antropología realizada por Enrique Maestas, 1997, que nos fue facilitada por Margarita Calderón.

Debates do NER, Porto Alegre, ANo I3, N. 2I P. II-48, JAn./Jun. 2012 
relacionadas; d) el posicionamiento respecto al sincretismo católico y la tradición conchera vs. los movimientos de purificación indígena (mexicanidad y algunas vertientes de neomexicanidad); e) la fuente de legitimidad de la danza chicana: México o Estados Unidos.

El grupo Xipe Totec, dirigido por dos discípulos de Yescas Lázaro Arvizu y Virginia Carmelo, es quien actualmente sostiene la Fiesta a Cuauhtémoc en el Parque México como su fiesta principal. Representa una de las vertientes más tradicionales dentro de la gama de grupos de danza de chicanos respecto a los ejes mencionados: se ha caracterizado por la adopción del ritual y símbolos concheros - con la consiguiente aceptación de su sincretismo católico, no tanto como creyentes sino desde una comprensión intelectual de los complejos procesos históricos de sincretismo como origen de la danza conchera -; la constante relación con grupos concheros mexicanos a través de la asistencia recíproca a fiestas; la búsqueda del reconocimiento de las mesas tradicionales mexicanas, y la radical distinción entre actividades políticas propiamente dichas y las ceremonias de danza, mismas que deberán mantener un carácter espiritual. De acuerdo a su capitana, Virginia Carmelo, en la danza es preciso "respetar el atuendo, pues la danza habla por sí misma" (no pancartas ni discursos), no obstante muchos de sus miembros son también miembros activos y líderes incluso de diversos movimientos propiamente políticos - como promoción del voto hispano y femenino por ejemplo, o por los derechos de los nativos norteamericanos como los Gabrielinos -, ${ }^{21}$ a cuyos eventos deben asistir sin atuendo. No obstante el énfasis en este distinción, no tienen objeción alguna en participar constantemente en eventos culturales e incluso espectáculos propiamente dichos, promovidos por entidades privadas o públicas. Dicen hacerlo con el objetivo de "[...] educar a la gente sobre el valor de esta tradición”, "[...] obtener fondos para la realización de viajes y fiesta obligación: Cuauhtémoc.”

\footnotetext{
${ }^{21}$ Los gabrielinos, también conocidos como tongbas, es el nombre genérico de tres tribus del grupo utoazteca que habitan en el sur de la actual California. Este grupo fue considerado extinto a mediados del siglo XX, sin embargo, en los resultados del censo del 2000 se registraron alrededor de mil gabrielinos. Su nombre proviene de la misión de San Gabriel Arcángel. Disponible en: http//:es.wikipedia.org/wiki/tongba. Acesso en: 4 mayo 2011.
} 
La ceremonia para recordar al último emperador Azteca en Tijuana empezó a celebrarse hace apenas diez años (1998). En Tijuana no había una tradición en torno al movimiento de la mexicanidad. Lo único que existía era una pareja de danzantes "chimaleros" (término peyorativo referido a que piden dinero en lugares públicos con el chimal o escudo) que danzaban en una plaza comercial. Sin embargo, fueron los danzantes concheros de San Diego quienes decidieron traer la tradición a Tijuana. Cuenta René Poblano, quien fue discípulo de Yescas, y posteriormente de Virginia Carmelo y de Lázaro Arvizu de Xipe Totec, que varios capitanes de danza estaban decepcionados por la manera en que se perdía el carácter sagrado de la danza ritual, por un lado por su exhibición como espectáculo, pero por otro por la politización radical que tuvo durante los años 70 a partir de que se retomó como bandera simbólica del movimiento chicano. Desde la perspectiva de Poblano había que recuperar el trabajo espiritual de la danza.

Recuerda que en el año 2000, él habló con Tata Cuaxtle, quien entonces trabajaba con las comunidades indígenas, y le propuso que hicieran el festejo a Cuauhtémoc en Tijuana. Él pensó que cómo era posible que un monumento tan bonito como el de Cuauhtémoc, estuviera tan desaprovechado y que sólo se usara para que los automóviles dieran ahí la vuelta (el monumento está en una glorieta de una avenida muy transitada, al estilo free way, pues para llegar a ella hay que cruzar por arriba un paso desnivel), pensó que cómo era posible que se celebrará en Los Angeles y no en Tijuana. Así que convenció al Tata de que pidiera los permisos para hacer ahí el festejo. Agrega que además era una ceremonia necesaria, pues se requería limpiar la imagen de la ciudad de Tijuana, que para los gringos es muy negativa. Representa todo lo malo, los vicios, la decadencia. Era necesario construir otra imagen de Tijuana y de México. Tata Cuaxtle organizó todo, y en la primera celebración vinieron los miembros de su grupo y otros grupos de San Diego. Su finalidad se sintetiza en: realizar un gran trabajo de purificación espiritual de Tijuana.

La organización del homenaje del 2008 al último rey azteca estuvo a cargo de Tata Cuaxtle, quien es líder espiritual del grupo de Danza Azteca Chicahuac Ollín, Tijuana, que en español significa: "Fuerza y movimiento". 
Este grupo formado por tijuanenses se originó en 2002 con la intención de "preservar, continuar y difundir las consignas de nuestros abuelos. Hemos logrado unir fuerzas, difundir el amor a la danza y el rescate de nuestra raíz mexica-azteca" Es un grupo que podemos catalogar dentro del movimiento cultural espiritual de la neomexicanidad, ${ }^{22}$ definido como un circuito sincrético donde confluyen y se sintetizan movimientos de la corriente espiritualista y esotérica de la Mexicanidad, redes New Age, comunidades rituales indígenas y danzas concheras: "Reivindica distintas tradiciones autóctonas (aztecas, mayas, olmecas o zapotecas) y que está dispuesta al diálogo con otras tradiciones culturales (la india, el Tíbet, el Islam); la doctrina mexicanista se encuentra aquí integrada a un proyecto planetario cuyo fin es el despertar la conciencia cósmica entre los hombres como resultado de la espiritualidad india”. ${ }^{23}$ El grupo tiene orígenes de la mexicanidad radical, importada por una pareja de danzantes provenientes del Zócalo de la ciudad de México y que tienen por ideólogo al gurú de la Mexicayotl, Arturo Meza. El grupo reconoce actualmente como guía espiritual a Tata Cuaxtle, ${ }^{24}$ a quien podemos considerar como un complejo nodo, cuya amplia trayectoria tanto política, ciudadana como espiritual le ha permitido tejer novedosos circuitos entre movimientos políticos de izquierda, con movimiento chicano de los ángeles, con los movimientos indígenas en México, en especial con los nativos de la Frontera norte, con los líderes del Consejo de Ancianos indígenas de Estados Unidos, (donde el es reconocido como anciano náhuatl, y se relaciono con dirigentes apaches, siux, lakotas, seris y, tongbas, etc.).

De esta manera, este actor nodo ha sido decisivo en tejer puentes interculturales entre un lado y otro de la frontera californiana. Sin embargo, en el grupo también participan "buscadores espirituales" que le dan un toque

\footnotetext{
${ }^{22}$ Miguel Olmos caracteriza a este grupo como "neo indígena", por ser mestizos de la ciudad que buscan rescatar y apropiarse de conocimientos "prehispánicos". Destaca que el grupo de Tijuana han generado una espiritualidad ecléctica que combinan elementos de mexicanidad, tradiciones lakotas, y neo esoteria oriental. (Olmos, 2008, p. 53-56).

${ }^{23}$ De la Peña, op cit. 2002, p. 81.

${ }^{24}$ Tata significa abuelo en náhuatl. Es un reconocimiento de mucho respecto y cariño entre los indígenas.
} 
hibrido con el movimiento espiritual Nueva Era, que ha sido caracterizado como neo mexicanidad, esta vertiente es practicada por ex integrantes de la Mancomunidad Indígena Solar (MAIS) que pertenecieron a la Gran Fraternidad Universal, de las brujas wicca, y un discípulo de tata Cachora, nativo yaqui de Tecate. Es un grupo abierto a la búsqueda de las raíces en distintas tradiciones indígenas y ancestrales: algunos además de asumirse como aztecas, practican la danza del Sol de origen navajo, participan también en el Kanto de la Tierra en Texas e incorporan el ritual lakota del temascal, heredado vía el Tigre Pérez. Acompañan año con año a los huicholes en la peregrinación anual sagrada de Wirikuta, en el estado de San Luis Potosí. Desde 2007 mantienen un santuario huichol o Kaliwey que les fue levantado por el Marakame Pablo Taisán y mantienen relación con el líder del Camino Rojo de la Mexicayotl, Arturo Meza, quien instauro la siembra del nombre, ritual en que varios de los congregantes se han iniciado en el camino rojo. Hay que recalcar que este grupo tiende a practicar la danza como un importante eslabón en la búsqueda nativista del saber y el espíritu "mexica" y que rechaza tajantemente el sincretismo indígena con la religiosidad popular católica, propio de las corporaciones de danza conchera. Tampoco implementa la danza en espectáculos o con fines comerciales.

El festejo a Cuauhtémoc de un lado y otro de la frontera consistió en tres momentos rituales: la velación, la peregrinación y el homenaje en el monumento a Cuauhtémoc, y la danza. A continuación las describiremos, y compararemos entre sí.

\section{COMPARATIVO DE LOS RITUALES}

A continuación, consideraremos los homenajes a Cuauhtémoc como rituales que representan dramas sociales, es decir: "unidades de procesos armónicos o disarmónicos que surgen en situaciones de conflicto" (Turner, 1974, p. 37). En ellos los actores expresan sus desacuerdos y posiciones diferenciales mediante la apropiación simbólica de las metáforas raíces (como es el símbolo de Cuauhtémoc) que simboliza la nación imaginada de Aztlán, la etnicidad mexicana india, la civilización y cultura azteca, y la 
mexicanidad), esas metáforas contribuyen a orientar el subconsciente de la identidad y la diferencia de la comunidad celebrante. En este sentido el ritual será atendido como drama social en cuanto es un episodio público, que surge del conflicto social (las políticas fronterizas), y que buscan la irrupción de dicha estructura. Atenderemos las celebraciones en describiendo sus fases que las componen.

a) Velación

Un rito que forma parte del sistema ritual de la danza es la velación. Ésta se realiza por las noches, en la víspera de la danza, y por lo regular es una celebración cerrada que se lleva a cabo en un oratorio. Yólotl González la describe como "una ceremonia en honor de los santos" y "las ánimas fundadoras guardianas y conquistadoras de los cuatro vientos", principalmente las almas de los capitanes y generales muertos y otras ánimas poderosas a las que mediante el ritual se logra atraer para que den su fuerza y protección al grupo que los está invocando (González, 2006, p. 76).

La velación en Los Angeles se realizó en el Downey Recreation Center, un centro recreativo auspiciado por el Lincoln Heights Neighborhood Council, cuyo uso fue gestionado por la capitana de Xipe Totec. En Tijuana se realizó en la explanada del Palacio de Gobierno, bajo una carpa improvisada.

A Los Angeles asistieron alrededor de cien personas, familias de migrantes establecidos o chicanos que venían de San Francisco, San Diego, Tucson, Pasadera, San Fernando, D.F., Monterrey, y un pequeño grupo de indígenas huicholes que están estudiando en LA. Participaron 14 grupos en total. En Tijuana asistieron los miembros del grupo anfitrión, dos capitanes importantes de danza conchera del estado de México y de Celaya Guanajuato; los miembros de varios grupos de danza azteca provenientes de Los Ángeles y de San Diego, donde cabe resaltar la presencia de René Poblano; un grupo de artistas y artesanos de la etnia pai pai, líderes del Conejo Guerrerense de Ensenada; maestros y alumnos de la Academia Semillas del Pueblo "Xinalcalmecátl de Los Ángeles

A medida que van llegando a la velación de Los Ángeles, los grupos entran cantando y con su estandarte: todos piden permiso dirigiéndose 
a la capitana del grupo convocante, hablan de las almas de los ancestros, de la obligación, de conquista, de tata Cuauhtémoc como el Tlatoani (emperador), de nuestra madre Guadalupe y algunos se refieren a ella como Tonantzin (nuestra madre, en náhuatl) y terminan con la afirmación conchera "El es Dios". Los que menos parecen concheros tradicionales son los del D.F. que además de pedir permiso y saludar hablan de cargarse de energías y de Ometeotl. ${ }^{25}$ Son los únicos que traen cintas rojas en la frente. Mientras los demás usan sonajas y mandolinas, ellos traen percusiones y se les pide discretamente no usarlas.

Por su parte en Tijuana ocurrió un fenómeno contrastante. Aunque la velación la comandaron los dos grandes capitanes concheros, ésta, a diferencia de las velaciones tradicionales, fue inclusiva y respetuosa de la diversidad de manifestaciones rituales En el sistema conchero tradicional las alabanzas son rigurosamente codificadas en correspondencia con el momento las fases del ritual. En Tijuana las alabanzas se dieron de manera espontánea, permitiendo que hubiera cantos en náhuatl de inspiración de Tata Cuaxtle, quienes al terminar en lugar de decir El es Dios, coreaban Ometéotl. También se entonaron cantos inspirados en los lakotas, como fue el canto del Oso creación de Sergio Ruiz, jefe del grupo de Danza Azteca Tenochtitlan (de los Ángeles), también se entonaron cantos pai pai de una artista de ese grupo étnico que asistió a la ceremonia por primera vez para vender su artesanía. Al terminar la velación, las señora pai pai “dio" la palabra y dijo "ha sido una fiesta muy bonita, nada parecido con lo que son nuestras tradiciones".

En la velación en LA a “tata” (papá o abuelo) Cuauhtémoc el ritual se llevó de acuerdo a la normatividad conchera. El culto se realizó en español. Se monto un altar donde estaban acomodadas las imágenes de la Virgen de Guadalupe, de Cuauhtémoc, y del ánima danzante del capitán Florencio Yescas. Cada que entra un grupo se da la bienvenida con alabanzas concheras y entregan las ofrendas, consistentes en veladoras y flores. Las sahumadoras

${ }^{25}$ Ometétol es para los mexicas la fuerza creadora. Es una sola deidad pero con carácter dual. Significa el señor-señora creador, conformado por la dualidad masculina-femenina: Ometecuhtli "el señor dos", y "Omecihuatli "la señora dos". 
los purifican a la vez que van poniendo cada objeto en el altar. Primero se formó una ofrenda circular de flores (ollin) frente al altar, luego se vistieron los bastones con las flores ofrendadas para levantar el Santo Xúchitl que es una cruz parecida a la custodia católica, y que en su carácter sincrético simboliza simultáneamente la cruz cristiana y también el calendario azteca. Ambos trabajos llevan unas dos horas, durante las cuales se cantan alabanzas. Cuando terminan, el altar está completo y ya nadie le da la espalda.

En Tijuana, la velación se llevó a cabo durante toda la noche hasta la madrugada, pues como me explicó uno de los organizadores “[...] se realiza durante toda la noche pues es cuando los ancestros bajan. Con las alabanzas deseamos agradar nuestro abuelo y que se sienta digno de su pueblo. Durante la noche las animas nos brindan su energía positiva”. Sin embargo, llama la atención que no hubiera un altar conchero con las imágenes de las santas animas y de los santos católicos. En cambio había dos grandes mantas pintadas por muralistas chicanos de los Ángeles, con imágenes de Cuauhtémoc, que evocaban el carácter guerrero del último emperador azteca. A los pies de uno de los murales se colocaron los ramos de flores multicolores con los cuales se diseño la santa forma y se vistieron los bastones ceremoniales. En el centro, sobre el piso se improvisó un santuario con sarapes de colores, y en uno de ellos se monto una especie de altar a los cuatro elementos con el copal, el agua, la luz de las velas. Se encendieron las velas, y cuando se extinguieron, se levantó la forma, pero no bajo la figura del Xuchitl, sino dibujando el nahui ollin, que significa cuatro movimientos. Esta traducción simbólica de la santa forma proviene de los rituales conocidos como chicontequiza, ritual creado por los seguidores de la mexicanidad radical con el fin de desechar los símbolos católicos, que ha sido traducido a la tradición mexica por los grupos de mexicanidad (González, 2006; De la Peña, 2002).

La última fase de la velación, tanto en Los Ángeles como en Tijuana, es el de la limpia o purificación con los bastones. Los bastones se visten con las flores previamente ofrendadas, mientras se entonan alabanzas especiales para pedir intercesión de las ánimas. En el caso de Los Angeles el símbolo recurrente tanto en formas como en movimientos es la cruz, que mantiene su sentido simbólico sincrético: la cruz cristiana y ollín. Antes de la limpia, 
se sahuman los bastones en forma de cruz, y se depositan frente el altar. Posteriormente se desarman y entonces la jefa de Xipe Totec nombra a dos capitanes de grupos visitantes a hacer limpia con los bastones. La limpia consiste en pasar el bastón alrededor del cuerpo de cada uno de los presentes, quienes hacen fila para tener su turno. Cada uno tiene que hincarse y poner sus manos en forma de cruz para recibir la limpia de bastones. El sahumerio, también se pasa alrededor los bastones y del cuerpo siempre en forma cruz. Según explicaron este rito tiene la finalidad de una limpia o purificación ritual a todos los ahí presentes. $\mathrm{Al}$ mismo tiempo se pide a las ánimas invocadas les den su protección para realizar su obligación del día siguiente: la danza entendida como una batalla.

La limpia de bastones se llevó igual en Tijuana, con la salvedad de fue el propio Tata Cuaxtle y una danzante del grupo de la ciudad de México Insignias Aztecas quienes lo presidieron. Para los del grupo Chincahuac Ollín este acto es también de purificación, pero supone recibir la energía de los ancestros, o ánimas, a quienes se dedicó la velación. En este caso se recibió la energía del abuelo Cuauhtémoc. La velación en Los Angeles no cumplió con la disciplina de velar hasta el amanecer, mientras que en Tijuana si lo hicieron, sin importar las inclemencias del clima. Este rasgo es criticado como una laxitud del American way of life que se contrapone al espíritu guerrero. Otro elemento de contraste, en que en los Ángeles el ritual se celebró en español, aunque en veces las instrucciones de logística se tradujeran al inglés. En cambio en Tijuana, Tata Cuaxtle siempre iniciaba sus discursos en un fluido náhuatl, a pesar de que ninguno de los presentes tiene dominio de esa lengua, y posteriormente traducía su mensaje al español.

b) "Cumpleaños" de Cuauhtémoc en Los Angeles: espectáculo cultural

La peregrinación se inicia al día siguiente en el lugar de la velación. Los participantes atuendados - es decir, portando el traje de danzantes - se agrupan en torno del altar a Cuauhtémoc, afinan, y cantan alabanzas. Luego la jefa del grupo convocante nombra los cargos oficiales para la danza capitanes y primera, segunda y tercera palabra. Se inicia la peregrinación a 
través de calles, avenidas y freeways. Chicos hijos de danzantes se adelantan a los cruces de calle y detienen el tráfico mientras pasan los danzantes. Se procura seguir en grupo y con cierto paso, pero no siempre se puede: se avanza de manera dispersa, procurando seguir el ritmo del tambor y atentos al tráfico. El paso de la marcha despierta mucha expectación entre los vecinos, que salen de sus casas, y de sus tiendas para vernos pasar. Aunque todo lo hispano forma parte del paisaje de Los Angeles los atuendos aztecas adquieren un carácter espectacular y exótico. $\mathrm{Al}$ atravesar por un puente un freeway enorme, se ve un contraste verdaderamente chocante entre plumas y concreto, autos y caracoles, huéhuetl y claxons. Marchar vestidos así requiere de valor, de orgullo, y demanda el reconocimiento de una diferencia. Pero se hace implícitamente, sin consignas ni mantas, sólo con los estandartes de los grupos.

La ceremonia a Cuauhtémoc (danza-concierto-baby dedication). El parque México ${ }^{26}$ es un pequeño espacio triangular en medio de los cruces de calles, con jardineras protegidas y presidido por una estatua a Cuauhtémoc en posición victoriosa. Al arribo de la caminata se encontraban unos cincuenta danzantes y unas ciento cincuenta personas como espectadores, rodeados de puestos de vendimia de objetos esotéricos y artesanías

${ }^{26}$ El Parque México se fundó dentro del Lincoln Park, que ha sido el centro de recreación del barrio Lincoln Heights, considerado el más viejo de Los Ángeles. En la década de los cincuenta la construcción de la autopista Golden State dividió en dos la ciudad de Los Ángeles y este barrio quedó marginado y fue ocupado por trabajadores chicanos y algunos migrantes chinos y vietnamitas. Se caracteriza actualmente por haberse convertido en espacio de pandillas y violencia. En 1981, a petición de diversas asociaciones mexicanas y chicanas, se dispuso dentro del Parque Lincoln un espacio nombrado Parque México, donde se han colocado estatuas de personajes de la historia de México, no sólo Cuauhtémoc, sino también Emiliano Zapata (líder de la revolución) o Agustín Lara (cantautor). En una placa se señala el objetivo de "conmemorar en un santuario cívico de la grandeza, historia y cultura del pueblo de México". El parque Lincoln es además sede de la Junta Hispana, que organiza actividades que se llevan a cabo periódicamente en cinco ciudades de Estados Unidos (Los Ángeles, Houston, Miami, Nueva York y Chicago) para reunir a las comunidades para compartir y recordar su cultura. Disponible en: www.lincolnheighstla.com,www.laparks.org,www.juntahispana.net www.publicartinla.com/sculptures/ Lincoln_Park/sculptures_descr.html. Consultados en: 20 enero 2011. 
latinoamericanas. A la distancia se encontraban patrullas de la policía como facilitadores del tránsito. Debajo de la estatua a Cuauhtémoc se puso un altar con ofrendas florales y frutales. Y frente a la estatua, dejando el espacio de la calle para los danzantes, se colocaron los músicos y su despliegue técnico propio de un concierto. Los instrumentos eran eclécticos: huéhuetls y teponaxtles (tambores aztecas) grandes y pequeños, de madera, de barro, de caparazones de tortuga de distintos tamaños, flautas de muchos tipos, con figuras antropo y zoomorficas prehispánicas, quenas andinas... A diferencia del papel jugado en las ceremonias concheras - como la velación - los músicos y cantores tienen en esta ceremonia pública un lugar central, como la danza misma, y se convierten en un espectáculo en sí. De hecho se reparte un programa en el que se señala su nombre y los puestos de alrededor venden sus $\mathrm{CDs}{ }^{27}$

La ceremonia comienza con palabras de la capitana del grupo anfitrión, Xipe Totec, quien dice hablar orgullosamente en el idioma de sus padres que fueron nativos norteamericanos gabrielinos, de los primeros que se establecieron en el área. Da la bienvenida a esta celebración "abierta a todos". En lugar de hablar del aniversario de la muerte y del nacimiento de Cuauhtémoc (que se conmemoran en los mismos días de febrero en diversas ciudades de México y Estados Unidos) y que remite a su significado de ritual de resistencia cultural indígena, se refiere a este homenaje como la celebración del "cumpleaños de Cuauhtémoc", imprimiéndole definitivamente un carácter apolítico. Sin ninguna consigna ni discurso, se hace el saludo a las cuatro direcciones, comienzan la danza con ritmos tradicionales concheros. El primer círculo se sincroniza rápidamente, no así los siguientes. No hay una unión completa, la danza se percibe dispersa. Muchos atuendos son combinaciones eclécticas entre conchero, azteca, prehispánico, deportivo y hippie. Los danzantes que no asistieron desde la velación muestran cierta improvisación. A medida que avanza la danza los músicos adquieren mayor relevancia y se introducen ritmos e instrumentos no tradicionales concheros, produciendo un sonido entre "tecno" y música

${ }^{27}$ De acuerdo al programa, se trata de Xavier Quijas Yxayotl, de América Indígena, Jhon Mosquera, Cayambe, y Martin Espino, Mexika.

Debates do NER, Porto Alegre, ANo I3, N. 2I P. II-48, JAN./Jun. 20 I2 
de "peña latinoamericana". Después de una hora se realizó un intermedio breve y dentro de éste se llevó también una ceremonia en náhuatl de "presentación" de una niña, o "Baby dedication" también anunciado en el programa. ${ }^{28} \mathrm{Al}$ término de la presentación, la jefa convocante da la palabra. Todos están muy complacidos y agradecen esta oportunidad de continuar celebrando a Tata Cuauhtémoc y cumplir con la obligación. Por la lluvia se invitó a regresar al Downey Center donde continúo la danza durante otras dos horas. Se sirvió comida para todos.

La ausencia de discursos durante el evento hace más necesario recurrir a la información de las entrevistas posteriores para conocer cuál es el sentido explícito de esta celebración para la capitana Virginia Carmelo, que en un difícil español expresa:

La ceremonia de nosotros es de Cuauhtémoc. Cuauhtémoc no es una figura, como un santo o como un dios o nada así. Es una figura que nosotros tenemos valor, de él, por lo que hizo él contra los españoles y por la comunidad de indígena. Entonces cuando nosotros juntamos a bailar en su honor, estamos ofreciendo la energía de nosotros, en su honor primero de él. Pero también es para cada uno de nosotros que estamos asistiendo allí, porque nosotros también tenemos que pelear fuerte, como él fue. Entonces nosotros estamos pidiendo al Creador que nos haga fuertes, que esta ceremonia salga bien, para cada uno de nosotros, de la forma y la manera que estamos ofreciendo al bailar, la energía de las danzas. (Virginia Carmelo en entrevista con Olga Olivas, enero de 2008).

c) El homenaje a Cuauhtémoc en Tijuana: Marcha, consignas y danza. La celebración emprendió a las 10 am con una danza en la explanada de Palacio de Gobierno, a los pies del monumento a Benito Juárez (lugar

\footnotetext{
${ }^{28}$ Esta ceremonia constituye una adaptación del rito de paso creado por los líderes del movimiento de la Mexicanidad, denominado "siembra de nombre", equivalente al bautizo, y que se realiza cuando un seguidor decide adoptar una nueva identidad como indígena, entendida como su verdadera identidad y simbolizada en un nombre náhuatl proveniente del Tonalpohualli o cuenta de los días aztecas de acuerdo con su fecha y hora de nacimiento.
} 
donde una noche antes se había realizado la velación). Para pedir permiso, se realizó, como se estila, el saludo a los cuatro vientos, que también se interpreta como una solicitud de permiso para iniciar la jornada. Posteriormente hubo una pequeña danza. A las 11 am el contingente de alrededor de 60 personas, formado por danzantes "aztecas" e indígenas con trajes étnicos, marchó por la avenida hacia el monumento a Cuauhtémoc.

La marcha adquirió, desde el inició un tono político, de denuncia por la política fronteriza asumido por el gobierno del Estados Unidos. En lugar de estandartes concheros, la marcha iba encabezada por dos grandes mantas, que fueron donadas al grupo de Tijuana por un famoso los muralistas urbanos de Los Ángeles. Una de ellas, donde se representaba a Cuauhtémoc rezaba así: ¡Raza tenemos que unirnos para tumbar las fronteras”. ${ }^{29} \mathrm{La}$ otra manta tenía impresa la siguiente consigna: "Ya basta con las malas injusticias. Racistas norte Amerikkanas, gavachas, robatierra, mentalidad diabólica, dividiendo a una gente con fronteras, drogas, pistolas fronteras y con una mentalidad de Diablo". Sobre el escrito, en letras rojas, se empalmaba el siguiente llamado: ¡Liberate!

También pudimos observar que el ritual, a diferencia de la velación, enfatizaba el carácter indígena, nativista del movimiento. No hubo concesión para los instrumentos concheros (de cuerdas), ni alabanzas, ni imágenes católicas, ni estandartes con santos y vírgenes. Solo había un estandarte, el del grupo de danza "Chicahuac Ollín Tijuana”, que carece de una imagen católica, y presenta un símbolo propio de la estética de indios del norte. Detrás de las mantas, los primeros que encabezaban el contingente eran los ancianos representantes de comunidades indígenas de la región de Tecate y de Valle de Guadalupe. Más atrás iban, en una pick up, dos miembros del grupo "Chicahuac Ollín Tijuana" tocando los huéhuetls (tambores prehispánicos) y atrás de ellos los danzantes. El contingente iba escoltado por dos motociclistas abriendo camino, y dos patrullas al final. Se cerraron tres carriles de la avenida, y la marcha

${ }^{29}$ Firmado por Murales Mictlán. East Lost Astlán.

Debates do NER, Porto Alegre, ANo I3, N. 2I P. II-48, JAN./Jun. 2012 
transcurrió entre los carros, que molestos por la interrupción del tráfico hacían sonar constantemente sus cláxones. Fueron escasos los espectadores, aunque abundaban los fotógrafos.

Al llegar a la glorieta donde se encuentra el monumento, se realizó el saludo a los cuatro puntos cardinales, sahumando los horizontes y tocando los instrumentos prehispánicos: ayoyotles y caracoles. Posteriormente un contingente subió por el monumento, y a los pies de tata Cuauhtémoc depositaron a manera de ofrenda los bastones de flores de la noche anterior.

El ceremonial se transformó por minutos en una manifestación política, con tintes de reivindicación indianista. Abajo, en la glorieta, Tata Cuaxtle emitió un discurso en un fluido náhuatl, con el que dio la bienvenida a los diferentes pueblos indígenas de la región: "paupau, cheneke, pai ai, kiliwa, kumia, kukapa, chaneque...” El discurso del líder espiritual contenía fuertes críticas a la política fronteriza:

Nuestros hermanos - dijo, refiriéndose a los indígenas - tienen familiares del otro lado no pueden visitarlos. Necesitan un papel para poder cruzar y poder compartir las ceremonias que compartían hace quizás 50 años atrás, hace quizás 100 años atrás... no había esto (refiriéndose a la frontera física y legal) todo esto era libre para ellos (los indígenas). Ellos no quieren ir a trabajar al otro lado. Hay hermanos indígenas paipai del otro lado, quizás porque creen que nosotros estamos de este lado, tenemos la necesidad de ir a trabajar allá. Nosotros no queremos venir a trabajar, queremos visitar, queremos conocer a nuestra familia, quieren juntos compartir de vuelta el calor de familia. Queremos compartir las ceremonias que compartíamos hace 50 años atrás. Entonces es triste como estamos. El hombre blanco ha traído muchas cosas negativas a nuestro pueblo. Esa es la verdad ¡Ometéotl! muchas gracias.

Todos los representantes de los grupos presentes hicieron uso de la palabra. Nadie, ni siquiera los capitanes concheros se atrevieron a corear su tradicional "Él es Dios", pues como señaló un capitán conchero: "Me refiero 
a Ometéotl por que hoy estamos frente al más digno de los representantes de nuestro indigenismo, no nada más de México, sino de nuestra América. ${ }^{30}$ En este acto, el problema transfronterizo se hizo sentir como un reclamo colectivo. Por ejemplo el mismo capitán conchero habló de la tradición como una manera de librar la batalla cultural frente al capitalismo y el neoliberalismo:

Hoy venimos a dejar un poquito de nuestros corazones. Algo que también dejaremos a nuestros hijos. Es un ejemplo a seguir, quizá nosotros no podamos tomar las armas, pero estas son nuestras armas: el ayacastli (sonaja), los ayoyotles, el caracol, los cantos. ${ }^{31}$ Digamos que estoy aquí, como reza ahí (aludiendo a la manta) para derribar las fronteras. Pues nuestra Patria ¡no se vende, se defiende! ${ }^{12}$ Ese es el sentir de todo danzante: ¡Ometéotl!

También se hicieron oír discursos a favor de la necesidad de mantener viva la tradición de los antepasados. Se habló de Cuauhtémoc como un modelo a imitar, por haber sido "un genuino guerrero azteca". También hubo quien aludió al cumplimiento de la profecía de Cuauhtémoc que se basa en la creencia sobre el próximo regreso de la cultura mexica. Y por último, y no menos importante, la Primera Palabra del grupo de Tijuana agradeció la presencia de todos para con su ritual contribuir en la purificación de energías en la sociedad de Tijuana:

${ }^{30}$ El capitán Flores, pertenece a uno de los grupos de mayor tradición entre las compañías concheras de la Ciudad de México, la mesa de los Hermanos Barrera, que fue fundada en 1926.

${ }^{31}$ Ambos son instrumentos musicales que se utilizan en la danza azteca. Ayacastli es el nombre náhuatl de la sonaja. Los ayoyotes ( $o$ ayoyotls en náhuatl) se refieren a un instrumento de percusión de la danza azteca, que consiste en semilla huecas de un árbol que se conocen como huesos de fraile. Estos se montan en muñequera y tobilleras y el sonido se logra con el movimiento del danzante.

32 En alusión al lema usado por el líder del principal partido de la izquierda en México, Andrés Manuel López Obrador, en contra de la venta de PEMEX. 
Ojalá que esta ceremonia nos ayude a purificar esta ciudad que es muy ruda. Esta frontera que tiene los dos rostros. Porque nos toca a veces enfrentar tareas difíciles. Pero gracias que ustedes están aquí nos brinda fuerza para continuar nuestra labor en esta ciudad en la que nacimos y en la que también vinimos a cantarle a nuestro abuelo. Muchas gracias por las palabra de todos y pues aquí seguimos hermanándonos.

Después de que los presentes dieron palabra a los pies del monumento de Cuauhtémoc, se cerró el evento realizando de nuevo el saludo a los cuatro puntos, y posteriormente se retiraron dando una vuelta por la glorieta donde se ubica el monumento.

d) Danza en Tijuana

La danza se retomó en la explanada, ahora a los pies del monumento a Benito Juárez. Además del grupo de Tijuana, cuyos atuendos variaban entre el estilo étnico (con bordados) y blanco de manta o algodón; el resto de los contingentes que provenían de Los Ángeles y San Diego, aunque todos eran de origen mexicano, ostentaban una estética más "guerrera azteca": los rostros con maquillaje de rayas negras, casi máscaras, parecido a la estética propuesta en la película de Mel Gibson Apocalipsis sobre los mayas. En el vestuario, había una estética híbrida: uso de zapatos que no son los guaraches de indios, ni las zapatillas de danzantes. Incluso habían quienes danzaban con tenis marca converse, lo cual sería muy mal visto en el centro de México. Un exceso de instrumentos de percusión: había ocho huéhuetls, ${ }^{33}$ así como de sahumadoras (eran nueve mujeres con sahumador). En un grupo conchero o azteca tradicional está función está restringida a la capitana de sahumerio y es un cargo honorífico que nadie más puede ocupar. Tampoco los invitados. También, como ya mencioné, llama la atención la ausencia de estandartes, que en las danzas rituales en torno a los santos patrones, constituyen el símbolo sagrado de cada grupo, donde además se manifiesta la identidad y la autentificación del grupo, es "La palabra". La disciplina

${ }^{33}$ Huehuétl es el nombre de un tambor cilíndrico que marca los compases de la danza azteca. Es considerado por los danzantes como "el corazón de la danza”. 
se mantuvo, aunque a diferencia de lo que se acostumbra en grupos tradicionales conchero-aztecas, les ofrecían agua y fruta mientras danzaban, practica que contraviene el carácter de guerrero, pues en la danza hay que aprender a disciplinar el cuerpo con el cansancio y el dolor. Por último vale la pena mencionar, que casi al final de la danza se realizó el reconocimiento de la entrega de bastón de mando a Tata Cuaxtle, el cual es uno de los honores y reconocimientos más importantes dentro de la tradición. Este fue un momento muy importante y a la vez alegre. Después Tata Cuaxtle, quien no es danzante, danzó en el centro del círculo, a manera de agradecimiento y comunión con los danzantes aztecas.

\section{SENTIDOS DE LA DANZA}

Las descripciones etnográficas nos demuestran que existen diferencias en la forma de practicar el ritual. En Los Angeles la autenticidad de la práctica de la danza no entra en contradicción con el sincretismo católico propio de la tradición conchera. Al contrario, la reconocen como la matriz a partir de la cual buscan eslabonar su identidad chicana en la tradición mexicana como raíz. En el caso de Tijuana hay la necesidad de traspasar las fronteras culturales de lo nacional a través del rescate de las raíces nativas que articular una etnicidad o nativismo espiritual panamericano. Los mismos contrastes detectamos en los usos sociales de la ceremonia de homenaje público a Cuauhtémoc: en Los Angeles a pesar de los importantes antecedentes políticos de la danza en el movimiento de reivindicación chicano, en la actualidad se colocó la ceremonia en un espacio apolítico, limitado a mostrar una práctica tradicional como fundamento de una pertenencia étnica pero en el plano casi folklórico del reconocimiento de la diversidad cultural de la ciudad. Como ha mencionado Olga Odgers en el contexto de EUA los símbolos católicos se convierten en un equivalente de etnicidad mexicana (Odgers, 2008), respondiendo a la vez a las necesidades de los chicanos y al modelaje etnizante de la identidad en el modelo norteamericano. Por su parte en Tijuana la ceremonia a Cuauhtémoc tomó sesgos de confrontación 
enfrentando a los mexicanos contra la política migratoria ejercida por el gobierno norteamericano, específicamente representada por el muro fronterizo. Las mantas chicanas proveían discursos iconográficos propios de los murales callejeros de Los Angeles, pero resituados a manera de estandartes en un ritual, en donde ponían de manifiesto el poder de Estados Unidos sobre los mexicanos. Se buscó capitalizar la diversidad indígena como un solo pueblo descendiente de Tata Cuauhtémoc que, aunque separado, está presente en ambos lados de la frontera. Y el ritual ofrecía puentes simbólicos para unir lo que el poder norteamericano fracturaba.

Este país que cree que puede imponer una frontera sobre lo que no tiene frontera. Mucha gente aquí se registró como de origen mexicano porque era más fácil decir eso en California que decir que eras apache, mojave o hasta africano. No tiene entonces ese registro, y ahora así les conviene (al gobierno), porque si fueran indígenas o nativos, tendrían el derecho de cruzar la frontera, porque es su territorio. Yo soy apache, mojave. Pero no tengo esos papeles. Somos nativos mexicanos entonces (dice retadora). Mexicanos aquí es indígenas. No son los gueritos educados los que se están viniendo, son mixtecas, totonacas... Pero no les conviene reconocerlos así, porque entonces no pueden impedirles pasar. (Mary Lou Valencia, entrevista con Cristina Gutiérrez, 23 de febrero de 2008)

La práctica de la danza se convierte en un capital social en ambos lados de la frontera, pero con distintos sentidos: para los chicanos de los Ángeles, les da una posibilidad de inserción en el mundo de la cultura y el espectáculo (que en su visión no debe ser restringido por el compromiso político visto como instrumentalización) inscribiéndose en una reivindicación de reconocimiento de la diferencia cultural pero dejando aparte la militancia política propiamente dicha, y sobre todo, la confrontación callejera. Para ambos potencialmente, pero sobre todo para los del lado mexicano, la etnización a través de la danza se convierte en la posibilidad de obtención de permiso legal de entrada a los Estados Unidos en virtud de la normativa internacional de libre tránsito a los indígenas en sus territorios de origen. 
Con todo, la danza ritual conchera ha sido valorada por sus practicantes como la fuente mas genuina de la recuperación de las raíces prehispánicas, sea en su versión híbrida con el catolicismo, o a través de los impulsos esencialistas de aztequizar e indigenizar esta práctica. A su vez la figura de Cuauhtémoc se coloca como un símbolo clave del encuentro intercultural y la búsqueda de las raíces, cuyo mito basado en la consigna del regreso de la cultura azteca, proyecta una utopía socio cultural basada en una nacionalidad que abarca un movimiento transnacional: Aztlán. Aztlán es también una metáfora espacial que reterritorializa los flujos migratorios y los territorios nacionales divididos por una frontera moderna. El ritual se realiza en el "espacio de los flujos" (Castells, 1999), carente de una contiguidad de lugar, pero posible por la temporalidad simultánea. Más que una conquista de espacios, lo que ocurre es una conquista de la memoria histórica, que permite recrear la noción del territorio y del sentido nacional. La eficacia simbólica del ritual descrito reside en su secuencialidad ritual; porque con ella genera una geografía con base en la simultaneidad del espacio practicado. Esta idea es compartida por Thomas Csordas, quien afirma que "lo simultáneo borra las distancias espaciales". ${ }^{34}$ El ritual a pesar de la línea fronteriza celebra unánimemente el retorno cíclico a la tierra prometida que a la vez es origen mítico y futuro utópico.

\section{REFERÊNCIAS}

ANDERSON, Benedict. Comunidades imaginadas. Reflexiones sobre el origen y el difusión del nacionalismo. México: FCE, 1993.

APPADURAI, Arjun. Modernity at Large. Cultural Dimensions of Globalization. Minneapolis, London: University of Minnesota Press, 1996.

ARGYRIADIS, Kali; TORRE, Renée de la, "El ritual como articulador de temporalidades: un estudio comparativo de la santería y de las danzas aztecas

34 "Una geografía global de lo sagrado", conferencia de Thomas Csordas en el Coloquio Transnacionalización de las religiones africanas, afroamericanas e indoamericanas, Guadalajara, 19 de octubre de 2010.

Debates do NER, Porto Alegre, ANo I3, N. 2I P. II-48, JAN./Jun. 2012 
en México". In: HOFFMANN, Odile; RODRÍGUEZ, María Teresa (Eds.). Los retos de la diferencia. Los actores de la multiculturalidad entre México y Colombia. México, CIESAS-CEMCA-IRD-ICANH, 2007. p. 471-508.

BAHBHA, Homi. Narrando la nación. In: FERNÁNDEZ BRAVO, Alvaro (Comp.). La invención de la Nación. Lecturas de la identidad de Herder a Homi Bhabha. Cap. 10. Buenos Aires: Manantial, 2000. p. 211-219.

BOURNE, Randolph. Trans-National America. In: Atlantic Monthly, v. 118 jul. 1916. p. 86-97.

CAPONE, Stefania. À propos des notions de globalisation et de transnationalisation. In: Civilisations, religions transnationales. V. LI, n. 1-2. Institut de Sociologie de l'Université Libre de Bruxelles, 2004. p. 9-21.

CAPONE, Stefania; MARY, André. In: Las translógicas de una globalización religiosa a la inversa. ARGYRIADIS, Kali; CAPONE, Stefania; DE LA TORRE, Renée; MARY, André (Coords.). En sentido contrario Transnacionalización de religiones africanas, latinoamericanas. México: CIESAS (en prensa).

CASTELLS, Manuel. El espacio de los flujos. In: La Era de la Información. V. I La sociedad red. México. Siglo Veintiuno Editores, 1999. p. 409-451.

CHATERJEE, Partha. Comunidad imaginada ¿por quién?. In: Gopal Balakrishnn (Ed.). Mapping the nation. Londres: Versi, 1996. p. 214-225.

CLIFFORD, James. Los productos puros enloquecen. In: Los dilemas de la cultura. Barcelona: Gedisa, 1995.

. Itinerarios transculturales. Barcelona: Gedisa, 1999.

COLONOMOS, Ariel (Comp.), Sociologie des réseaux transnationaux. Communautés, entreprises et individus: lien social et système international. París: l'Harmattan, 1995.

CSORDAS, Thomas J. (Ed.), Transnational Transcendence: Essays on Religion and Globalization. Berkeley: University of California Press, 2009.

DE LA PEÑA, Francisco. Los hijos del sexto sol. México: INAH, 2002. 
DE LA TORRE, Renée. La estetización y los usos de las danzas concheras. In: ARGYRIADIS, Kali et al., Raices en movimiento. Prácticas religiosas tradicionales en contextos translocales. México: El Colegio de Jalisco / CIESAS / IRD / CEMCA / ITESO, 2008. p. 73-110.

DE LA TORRE, Renée; GUTIÉRREZ ZÚNIIGA, Cristina. La neomexicanidad y los circuitos new age: ¿un hibridismo sin fronteras o múltiples estrategias de síntesis espiritual. Archives de Sciences Sociales des Religions. In: dossier Religions amérindiennes et circuits de spiritualité new age. París: éditions de L'école des Hautes études en Sciences Sociales, n. 153, 56 anné, 2011. p. 183-206.

DE LA TORRE, Renée; ZÚÑIGA, Cristina Gutiérrez (s/f). Atravesados por la frontera. Anáhuac-Aztlán: danza y construcción de una nación imaginada. In: ARGYRIADIS, Kali; CAPONE, Stefania; DE LA TORRE, Renée; MARY, André (Coords.). En sentido contrario Transnacionalización de religiones africanas, latinoamericanas. México: CIESAS (en prensa).

DEGENNE, Alain; FORSÉ, Michel. Les réseaux sociaux, une analyse structurale en sociologie. Paris, Armand Colin, 1994.

EL PROCESO RITUAL. Estructura y antiestructura. Madrid: Taurus, 1980.

GALINIER, Jacques; MOLINIÉ, Antoinette. Les néo-indiens. Une religion du III millénaire, París: Odile Jacob, 2006.

2006.

. Les neo-indiens. Une religion du III ${ }^{\circ}$ millenaire. París: Odile Jacob,

GARCÍA CANCLINI, Néstor, Culturas híbridas. Estrategias para entrar y salir de la modernidad. México: Grijalbo, 1990.

. Culturas hibridas. Estrategias para entrar y salir de la modernidad. México, Grijalbo, 1990.

GONZÁLEZTORRES, Yólotl. Danza tu palabra. La danza de los concheros. México: CONACULTA-INAH-Plaza y Valdés, 2006. 
GRUZINSKI, Serge. La guerra de las imágenes. De Cristóbal Colón a "Blade Runner" (1492-2019). México: Fondo de Cultura Económica, 1990.

HALL, Stuart. "Lo local y lo global: globalización y etnicidad". Traducción de Pablo Sendón. 1991. Disponible en: www.colonautas.edu.'pe/Biblioteca Virtual de Ciencias Sociales. Consultado en: 1 sept. 2010.

KEARNY, Michael. Fronteras fragmentadas, fronteras reforzadas. In: MUMMERT, Gail (Ed.). Fronteras Fragmentadas. México: El Colegio de Michoacán, 1999.

MAESTAS, Enrique. Danza Azteca en Aztlan. The difusión of Danza Azteca in the United States. La tesis de maestría en Antropología, Universidad de Colorado en Boulder, (Honors Thesis for Departmental Honors), 1997.

MAGNANI, José Guilherme. O Circuito neo-esotérico na cidade de São Paulo. In: CAROZZI, María Julia (Ed.). A Nova Era no MERCOSUR. Petrópolis: Editora Vozes, 1999. p. 27-46.

MARCUS, Georges, Ethnography in/of the World System: the Emergence of Multisited Ethnography. In: The Annual Review of Anthropology, v. 24, 1995. p. 95-117.

PEW HISPANIC CENTER. "Estimations based on March 2005 Current Population Survey”. Disponible en: http://pewhispanic.org/files/reports/61. pdf. Consultado en: 1 sept. 2010.

ODGERS, Olga. Construcción del espacio y religión en la experiencia de movilidad. Los Santos Patronos como vínculos espaciales en la migración México-Estados Unidos. In: Migraciones Internacionales, V. IV. n. 3, El Colegio de la Frontera Norte, 2008. p. 5-26.

OLMOS AGUILERA, Miguel. Las creencias indígenas y neo-indias. En: la frontera MEX/USA. In: TRACE 54, México: Centro de Estudios Mexicanos y Centroamericanos, 2008. p. 45-60.

QUIJANO, Aníbal. “QQué tal raza”!, Revista Venezolana de Economía y Ciencias Sociales, n. 1, Caracas, 2000. 
RODRÍGUEZ, María Ángela. Tradición, identidad, mito y metáfora. México, CIESAS-Porrúa, 2005.

SEGATO, Rita Laura. La nación y su otros. Raza, etnicidady diversidad religiosa en tiempos de Politicas de la identidad. Buenos Aires: Prometeo, 2007. TORRES RAMÍREZ, Gustavo Rubén. Vivir e imaginar la ciudad. Tijuana: imaginarios urbanos de una ciudad fronteriza. Guadalajara, Tesis de Maestría en Comunicación, Departamento de Estudios de la Comunicación Social. de la Universidad de Guadalajara, 2004.

TURNER, Victor. Dramas, Fields, and Metaphors: Symbolic Action in Human Society, Cornell University Press, 1975.

US Customs and Border Protection Public Affairs Office, "Statistics" disponible en la página "Migration Information Source" generada por el Migration Policy Institute. Disponible en: http://www.migrationinformation.org/Feature/display.cfm?id=407. Consultada en: 1 sept. 2010.

US Department of State Visa Statistics, "Southern border Statistics" disponible en la página "Migration Information Source" generada por el Migration Policy Institute http://www.migrationinformation.org/Feature/ display.cfm?id=407, consultada el 1 de septiembre de 2010 .

VALENZUELA ARCE, José Manuel. Al otro lado de la línea. Representaciones socioculturales en las narrativas sobre la frontera México-Estados Unidos. In: Revista Mexicana de Sociología, año LXII, n. 2, México, Universidad Nacional Autónoma de México, 2000. p. 125-149.

WIKIPEDIA, enciclopedia libre en español, "Tongva". Disponible en: http//:es.wikipedia.org/wiki/tongva. Consultado en: 4 mayo 2011.

, "Demographics of Los Angeles". Disponible en: http://en.wikipedia. org/wiki/Los_Angeles\#Demographics. Consultado en: 1 sept. 2010. 